\title{
Diagnostic perplexity of panoramic radiograph
}

\author{
Sheikh Bilal Badar, Robia Ghafoor
}

Department of Surgery, Aga Khan University Hospital, Karachi, Pakistan

\section{Correspondence to} Dr Sheikh Bilal Badar, sheikh.badar@aku.edu

Accepted 2 July 2016

\section{DESCRIPTION}

A 14-year-old girl presented to the dental clinic with a history of a fall and blow to her upper front teeth. After initial management by the oral surgeon she was referred to the endodontic department for the management of her fractured maxillary incisors. Her medical history was unremarkable. Intraoral examination revealed complicated crown fracture on maxillary central and lateral incisors. Panoramic radiograph (figure 1) showed fractured maxillary incisors involving pulp and horizontal root fracture at apical third of tooth number 21(Fédération Dentaire Internationale) that raised a question to the prognosis of this tooth. Since panoramic views are not a good diagnostic tool to assess anterior teeth, we had taken occlusal view (figure 2) and periapical view radiographs (figure 3) at different angles to confirm horizontal root fracture. These radiographs showed a completely different scenario. We could see a separate mass (odontome/supernumerary tooth) having a canal space, adjacent to the root of tooth number 21 and the root of the



Figure 1 Panoramic radiograph showing fracture line at the junction of middle and apical third of root of tooth number 21(Fédération Dentaire Internationale).

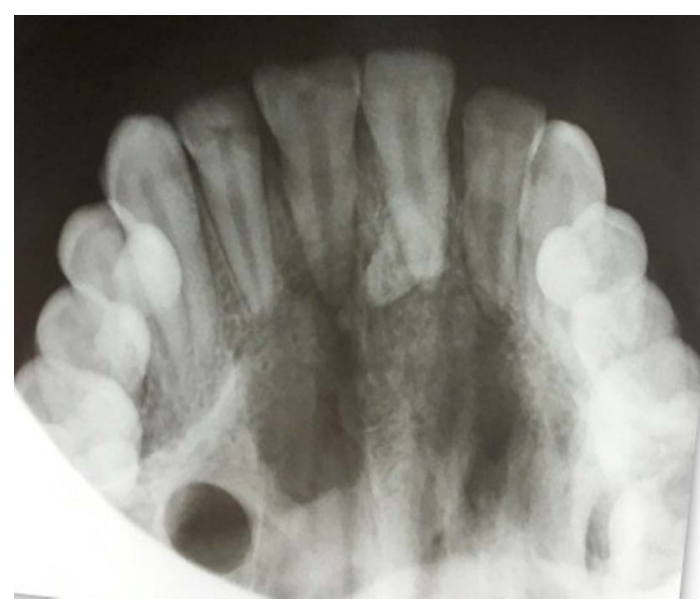

Figure 2 Occlusal radiograph showing the presence of supernumerary tooth or odontome adjacent to the root of tooth number 21(Fédération Dentaire Internationale).

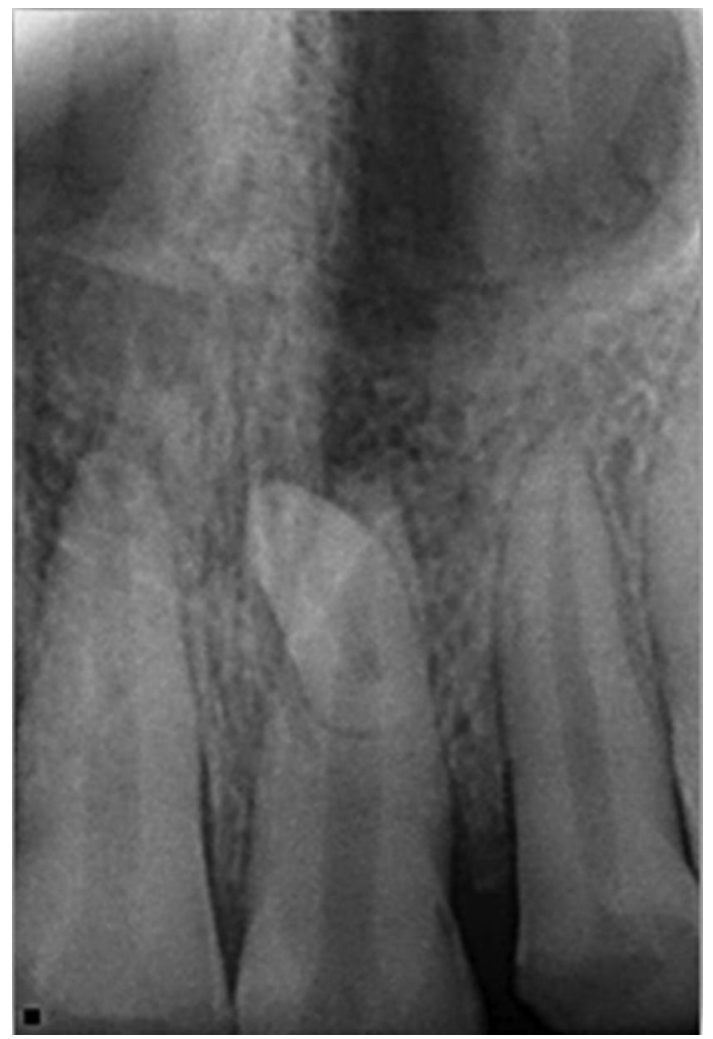

Figure 3 Periapical view showing the presence of separate mass adjacent to the root of tooth number 21(Fédération Dentaire Internationale).

tooth did not show any abnormality. Thus, further management was carried out according to the diagnosis of complicated crown fracture of maxillary incisors.

Panoramic radiograph is considered to be an important and useful screening tool for radiological assessment in all dental specialties. Its importance cannot be negated in the survey of maxillofacial region and diagnosis of suspected maxillofacial fractures. ${ }^{1}$ However, the image clarity in the anterior region is limited, therefore, in conjunction to panoramic radiograph periapical radiographs are also recommended at different angles to rule out any dental fracture. ${ }^{23}$ Relying solely on panoramic radiograph might lead to inadequate diagnosis.

\section{Learning points}

- The image clarity of panoramic radiograph is limited in the anterior region.

- Periapical radiographs at different angulations are necessary to rule out any dental fracture.

- Depending solely on the panoramic radiograph might end up in inadequate treatment. 
Contributors SBB was involved in drafting the article and management of patient RG was involved in the final review of the article and provision of treatment to the patient.

Competing interests None declared.

Patient consent Obtained.

Provenance and peer review Not commissioned; externally peer reviewed.

\section{REFERENCES}

1 Decusara M. Use of orthopantomogram in dental practice: a statistical study. Int Jr Med Dent 2011;1:389-92.

2 Chien HH, Chen CS. The applications and limitations of conventional radiographic imaging techniques. Clin Maxillary Sinus Elevation Surg 2014;17:9-30.

3 Diangelis AJ, Andreasen JO, Ebeleseder KA, et al. International Association of Dental Traumatology guidelines for the management of traumatic dental injuries: 1. Fractures and luxations of permanent teeth. Dent Traumatol 2012;28:2-12.

Copyright 2016 BMJ Publishing Group. All rights reserved. For permission to reuse any of this content visit http://group.bmj.com/group/rights-licensing/permissions.

BMJ Case Report Fellows may re-use this article for personal use and teaching without any further permission.

Become a Fellow of BMJ Case Reports today and you can:

- Submit as many cases as you like

- Enjoy fast sympathetic peer review and rapid publication of accepted articles

- Access all the published articles

- Re-use any of the published material for personal use and teaching without further permission

For information on Institutional Fellowships contact consortiasales@bmjgroup.com

Visit casereports.bmj.com for more articles like this and to become a Fellow 